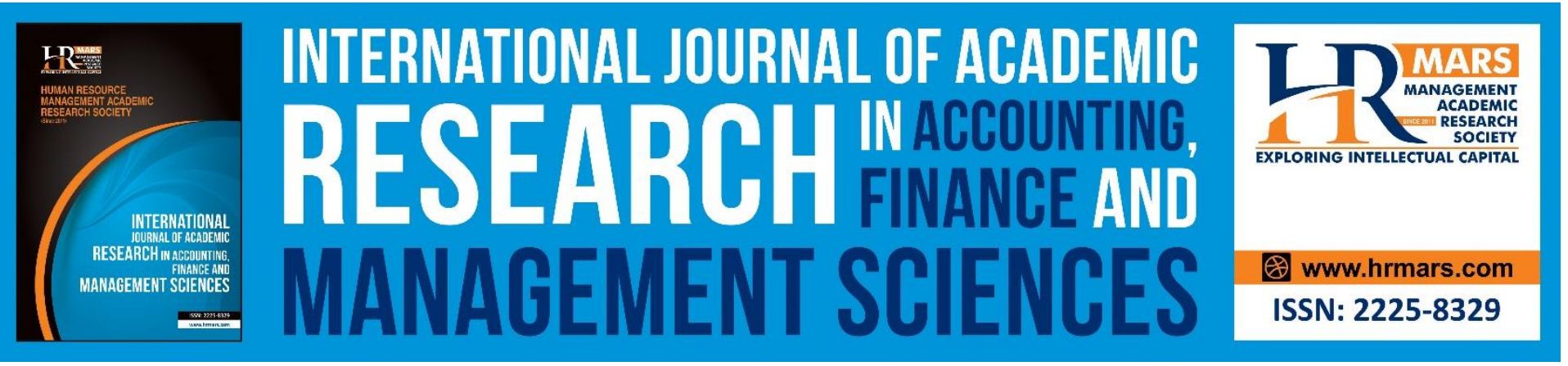

\title{
Bay Al-istirsal and its Ruling in Sharia Perspective
}

\section{Nik Abdul Rahim Nik Abdul Ghani, Mohd Borhanuddin Zakaria}

To Link this Article: http://dx.doi.org/10.6007/IJARAFMS/v10-i3/8048

DOI:10.6007/IJARAFMS /v10-i3/8048

Received: 18 June 2020, Revised: 21 July 2020, Accepted: 25 August 2020

Published Online: 29 September 2020

In-Text Citation: (Abdul Ghani, \& Zakaria, 2020)

To Cite this Article: Abdul Ghani, N. A. R. N., \& Zakaria, M. B. (2020). Bay Al-istirsal and its Ruling in Sharia Perspective. International Journal of Academic Research in Accounting, Finance and Management Sciences. 10(3), 380-388.

\section{Copyright: (c) 2020 The Author(s)}

Published by Human Resource Management Academic Research Society (www.hrmars.com)

This article is published under the Creative Commons Attribution (CC BY 4.0) license. Anyone may reproduce, distribute, translate and create derivative works of this article (for both commercial and non-commercial purposes), subject to full attribution to the original publication and authors. The full terms of this license may be seen at: http://creativecommons.org/licences/by/4.0/legalcode

Vol. 10, No. 3, 2020, Pg. 380 - 388

Full Terms \& Conditions of access and use can be found at http://hrmars.com/index.php/pages/detail/publication-ethics 


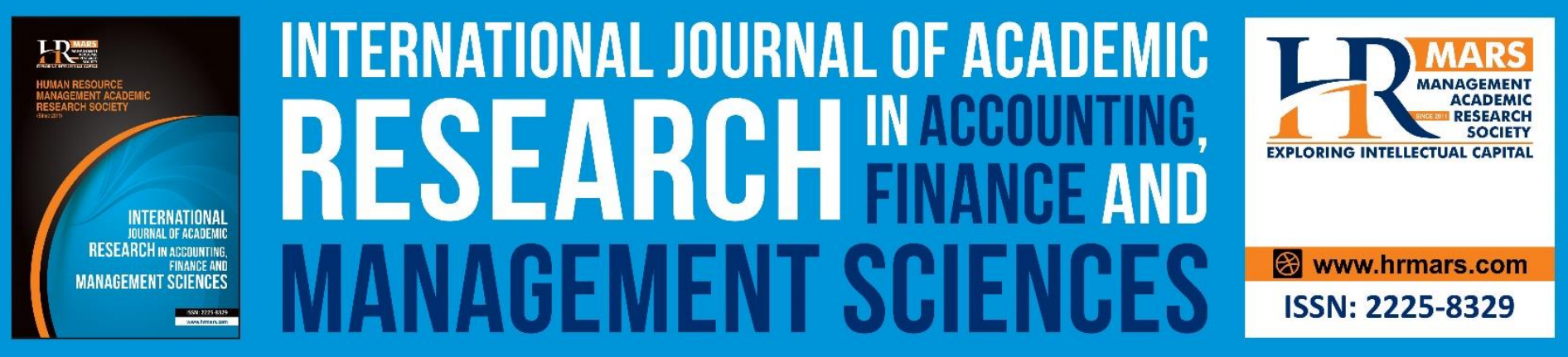

\title{
Bay Al-istirsal and its Ruling in Sharia Perspective
}

\author{
Nik Abdul Rahim Nik Abdul Ghani \\ Research Centre for Sharia, Faculty of Islamic Studies, Universiti Kebangsaan Malaysia \\ Email: nikrahim@ukm.edu.my
}

Mohd Borhanuddin Zakaria

Department of Shari'ah, Faculty of Islamic Contemporary Studies, Universiti Sultan Zainal Abidin.

\begin{abstract}
This paper seeks to clarify the status of bay istirsal as a type of Islamic contracts according Muslim scholars. The discussions revolve around its meaning, rules and the acceptance of this contract among Muslim scholars. This paper analyses the meaning of bay istirsal by referring to the scholarly works on Islamic jurisprudence. Based on the analysis conducted, the study reveals that bay istirsal has been discussed by classical jurists under the concept of ghabn or khiyar ghabn (option of deceit). This present paper discusses the issue thoroughly and arrives at a conclusion that bay istirsal could be considered as a special contract that has its specific rules and implications in Sharia.
\end{abstract}

Keywords: Istirsal, Ghabn, Price, Jahalah, Muamalat, Khiyar.

\section{Introduction}

Generally a sale (bay') is an exchange of one item for another or the exchange of an owned commodity for another in a beneficial and special manner. Sales are permitted with supporting evidences from the Quran, the hadith and ijma'. It is one of the basic conditions for the validity of a sale in Shariah that the price of a sale contract must be fully specified. Otherwise, the contract is void for want of knowledge. This price should be agreed upon by two contracting parties. Even though a contract originally is based on mutual consent between two parties, Islamic jurists also concerned about selling an asset above the value of the asset. Thus, when discussing the issue of fair price, jurists will touch the topic of bay' istirsal. Bay istirsal is one of the controversial sale contracts whereby the purchaser allows other the seller to set the price of the subject of the transaction based on his trust in the seller. It also has a solid relationship with the discussion of ghabn fahish whether a contract can be terminated if there is ghabn fahish. One should bear in mind that so far there is no product which has been discovered by using this principle as compared to other financial principles. Perhaps, the reason is because the disputes among scholars as regards to the validity of this contract. Hence, this study aims to analyze the ruling of bay istirsal from the Sharia perspective by taking into account evidences for each opinions of jurists. 
INTERNATIONAL JOURNAL OF ACADEMIC RESEARCH IN ACCOUNTING, FINANCE AND

MANAGEMENT SCIENCES

Vol. 10, No. 3, 2020, E-ISSN: 2225-8329 @ 2020 HRMARS

\section{Overview of Bay Istirsal}

Generally, the term bay istirsal is also known as bay mustarsil, bay isti'man or bay istislam. According to The Encyclopaedia of Islamic Law published by Ministry of Awqaf of Kuwait (1983), bay istirsal falls under the types of buyu' amanah or sale of trust. It is mentioned in the encyclopaedia:

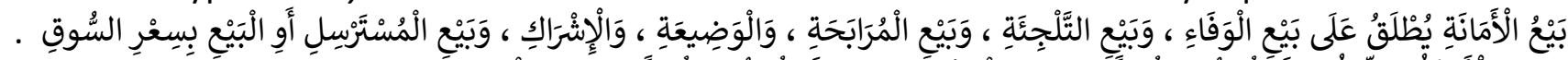

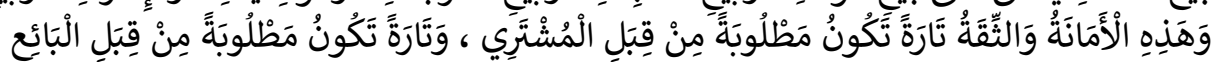

Meaning: "Sale of trust refers to bay al-wafa', bay al-talji'ah, bay murabahah, bay wadi'ah, bay ishrak and bay al-mustarsil or sale at market price. Sometimes this trust and belief required from the purchaser and sometimes from the seller".

Besides that, when discussing the effect of ghabn on contract, jurists will normally touch in quite detail three types of practices namely talaqqi al-rukban, najash and mustarsil (Omar et. al., 2011). Thus, a separate discussion on the topic of bay istirsal is rarely found in classical writings of figh as well as in modern writings. Its discussion is often associated with the topic of ghabn and khiyar ghabn.

Literally, the word istirsal as described by Ibn Manzur (n.d,) means having a domestication and peace of mind with someone and trust in all of his statements. The origin of its meaning is stillness and steadiness (السكون والثبات). However, in fiqh writings, jurists normally use the word istirsal to indicate three different meanings as follows:

- Used in sales contract which conveys the meaning of someone who confidences or trusts with other person. This meaning is the concern of this paper.

- Used in the concept of wala' (love, support, help) which means to turn back, to connect with someone

- Used in the concept of hunting of animals which means letting your dog to catch animal

Technically, Muslims jurists use different expressions to imply its meaning. Malikiyyah (Ibn Juzayy, 2013) defines it as follows:

$$
\text { وأما الاسترسال فهو أن يقول الرجل للبائع بع مني بسعر السوق أو بما تبيع من الناس }
$$

Meaning: "And istirsal, it is that a person says to the seller, sell to me as market price or buy from me as you buy from other people".

It seems that Maliki scholars do not look at the attribute of the purchaser whether he is an ignorant person or not. Instead, they consider bay istirsal as a trust sale where a person enters into a sale contract based on his trust with the other party.

On the other hand, Shafici scholars tend to explain the meaning of mustarsil rather than define bay istirsal as a particular type of sale. Al-Haytami (n.d), for instance,) for instance said that mustarsil is a person who does not know the price of goods. Likewise, Hanbali scholars also prefer to explain the meaning of mustarsil. They define mustarsil as a person who does not know how to bargain. Sometimes they define it as an ignorant person about the market price. (al-Mardawi, n.d; Ibn Qudamah, 1985) 
Based on all definitions mentioned above, it can be concluded that bay al-istirsal is a type of sale that occurs when one of the contracting parties allows the other party to set the price of the subject of the transaction because he himself is ignorant of the market price, by saying "buy from me as you buy from other people, or sell to me as you sell to other people" (ISRA, 2010). It also can be intended as a sale which is based on trust in which a buyer does not haggle over the price of a commodity and is willing to buy at the price quoted by the seller (Khan, 2003). Thus, this contract is considered as part of trust sale and it was condemned by the Prophet a severe term if a cheating element present. In the hadith narrated by al-Bayhaqi (n.d), the Prophet (pbuh) said: "Cheating the mustarsil constitutes usury (riba)". The cheating of an unsophisticated entrant into the market (ghabn al-mustarsil) had been equated with riba which indicates the prohibition of such an act to be practiced by market participants.

Therefore, bay istirsal is a contract of an easy-going customer who does not bargain or who is ignorant about the market price. However, he trusts what the sellers say about the real value of a particular article. It also means a contract of a customer who believes and trust in the seller to determine the price of goods. The parties involved in the contract have a fiduciary relationship in which the seller is entrusted with the buyer's confidence that he will tell the truth or reveal those facts which he is the seller to sell it at market price. Upon having such a trust placed in him the seller is required by law to disclose the true value of the article and sell it at the market price. Any given price higher than the normal price would be regarded as fraud (al-Bashir, 2008).

\section{Types of bay Istirsal}

In general, as referring to the aforementioned definitions, it is clearly shown that there are several types of bay istirsal as follows:

i. A person who trusts the seller for his good characteristic such as a well-known person in the market as regards to his religion or trustworthiness. Since that, he trusts the seller and enters in a contract with him.

ii. An ignorant person who does not know the price of goods and tells the seller about that, so the seller takes advantage to exploit the buyer by overcharging on the price as compared to the market price.

iii. An unsophisticated or weak person who does not know to bargain in sale matters, so the seller exploits him for his weakness by overcharging on the price.

In terms of having a similar name, it is possible to consider all of them as mustarsil whether he is ignorant with the price, or does not know to bargain in sale contract or trusts and believes the seller. The reason is because the word mustarsil literally is suitable for all of them.

\section{Analysis of views of scholars on bay istirsal}

Muslims scholars are divided into two mainstreams on the legality of bay istirsal. The first opinion acknowledged bay istirsal as a form of contract similar to other types of contracts which justified by general rule of contract in Islam. Meanwhile the second mainstream opines that bay istirsal is a contract which has its particular rules and implications similar to bay najash and talaqqi rukban. 


\section{i) First View}

According to the jurists of Hanafi and Shafici schools of thought, bay istrisal is justified by general rules of contract in Islam. This is because any decreasing or increasing of the total price of commodity sold does not prevent the bindingness of the contract like other contracts provided that the commodity sold must be in a good condition. Therefore, the ignorant purchaser (mustrasil) has no right to revoke the contract as the reduction of the value/price of thing sold does not constitute a reason for cancellation of contract. The view of Hanafi is basically based on their opinion that a deceived person does not have option of revocation. (Al-Kasani, 1986)

In this regard, al-Nawawi in al-majmuc elaborates the ruling of this type of sale according to Shafici school of thought by saying:

وقد قال أصحابنا يكره غبن المسترسل واطلاق الكراهة في ذلك محمول على ما إذا لم يستنصحه المسترسل أما إذا استنصحه فيجب

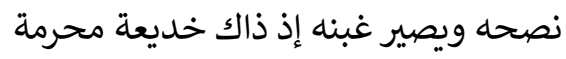

Meaning: "Our ashab (scholars) said that it is not allowed (karahah) to do ghabn mustarsil (overcharging ignorant purchaser). Mentioning karahah in this ruling refers to a situation when that person (mustarsil) did not demand advice. Meanwhile, if he is demanding advice, then it is compulsory to advise him and the act of overcharging (ghabn) becomes a form of prohibited cheating (al-Nawawi, n.d).

This opinion tends to validate the contract of mustarsil, but it is recommended to be omitted (karahah). However, it will be prohibited or haram if the buyer demanded advice but the seller cheated him by charging him with a price higher than the market price.

Hanafis' jurists also opine that the existence of ghabn doesn't give the right of cancellation for the purchaser. Nevertheless, some of Hanafi jurists say that a deceived person (al-maghbun) may revoke the contract if the element of flagrant misrepresentation or excessive ghabn can be proved. In this connection, Majallat al-Ahkam al-Adliyya, under the article357 states: "If one of the two parties to the sale deceives the other, and flagrant misrepresentation is also proved to be present in the sale, the person so deceived can cancel the sale".

This opinion was based on the verse of al-Quran from al-Nisa' (4: 29) which asserts that each contract which is completed by mutual consent between contracting parties is regarded as permissible (halal), and the deceived party has entered the contract by his own consent and option. In addition to that, the absence of ghabn is not a necessary pillar or condition for the validity of the contract. ${ }^{1}$ Thus, they opine that the contract is valid without giving a right of revocation to the purchaser.

\section{ii) Second view}

Malikiyyah and Hanabilah are of the opinion that this type of sale has its own rules and specific implications from Shariah perspective. The basis of this opinion is due to several prohibited elements that exist in this sale, which are ghabn, taghrir and tadlis on the ignorant party.

${ }^{1}$ See the elaboration on evidences in al-Nishwan, Hukm al-ghabn wa atharuhu fi al-aqd, in Majallat al-Adl p. 94. 
Ibn Taymiyyah was asked about this point of issue and he answered by saying:

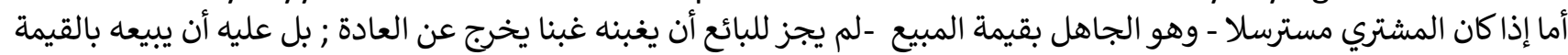

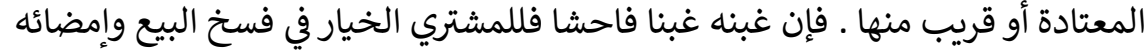
Meaning: "If the purchaser is mustarsil who is ignorant with the price of goods, then it is not allowed to the seller to overcharge him in the way that is out of custom. But, the seller is obliged to sell it with the usual price or close to that. If the seller overcharges the purchaser by imposing a major ghabn, then the purchaser has the option whether to revoke the sale or accept it" (Ibn Taymiyyah, 1995).

It is obviously shows that Ibn Taymiyyah suggests that a seller should earn profit in commonly accepted manner without destroying their interest and the interest of the buyer. His statement indicates that he is against abnormal rate of profit exploitative (ghabn fahish) of a situation where people are ignorant of market conditions (Islahi, 2005). It is important to note that this opinion also validates the contract of bay istirsal, but the existence of ghabn may affect its validity. As a result, they give the right of cancellation to the party who suffers losses from overcharging practice.

The jurists of this opinion base their view on several evidences from the Prophetic traditions. One of them is that the Prophet said:

$$
\text { غبن المسترسل ريا }
$$

Meaning: "Cheating the mustarsil constitutes usury (riba)".

This hadith is narrated by al-Bayhaqi from Jabir, Anas and Ali as stated by al-Suyuti (1996) in Jami' al-Ahadith vol. 14 p. 385.In other narration, the Prophet (pbuh) said: "Cheating the mustarsil is impermissible (haram)". This hadith narrated by al-Tabarani and the chain of its reporter is weak (alSuyuti, 1996 ).

The stronger evidence is the hadith reported by Ibn Umar that one of the companions told to the Prophet that he always had been cheated in the trading business. The prophet then advises him: "Whenever you are in trade, say: There is no cheating". (al-Bukhari, 1987; Muslim 1995). These evidences indicate that the contract of istirsal is valid provided that there is no element of cheating and deception. These elements may affect the validity of this contract and accordingly it gives to the deceived person a right to cancel the contract.

\section{The Preferred Opinion}

In order to obtain the weightiest opinion, the evidences given by each view must be analyzed. It is known that the jurists of the first opinion do not recognize istirsal as a particular contract and they opine that there is no khiyar for mustarsil person. They also give response on the evidences of the second opinion saying that the ahadith presented by them are weak. For instance, the first hadith was narrated by al-Bayhaqi and was graded as very weak. The hadith also is graded as void (batil) by al-Albani. Likewise, the second hadith in another narration also was graded as weak by many of scholars.

However, the third hadith is an authentic hadith which was agreed upon by al-Bukhari and Muslim. Undoubtedly, the mustarsil person also includes in the meaning of this hadith as the 
INTERNATIONAL JOURNAL OF ACADEMIC RESEARCH IN ACCOUNTING, FINANCE AND

MANAGEMENT SCIENCES

Vol. 10, No. 3, 2020, E-ISSN: 2225-8329 @ 2020 HRMARS

reduction in the price of goods is considered as oppression and tyranny, thus, it is against Shari'ah which requires justice and fairness in business dealings.

For that reason, based on the previous evidences, it can be concluded that the view of Maliki and Hanbali which holds that bay istirsal possesses its own ruling and implications is a correct opinion as the third hadith is an authentic hadith which is agreed upon narrated by most of great hadith scholars such as al-Bukhari, Muslim, Malik, Ahmad, al-Tirmizi, al-Nasa'i and Ibn Majah. In other narration, the Prophet has given three days of option to revoke the contract for one who has stipulated the absence of cheating (khadi'ah) and misrepresentation (ghabn) in the contract.

Additionally, by applying the principle of al-ibrah bi umum al-lafz la bi khusus al-sabab (the lesson is taken from a verse or a hadith should be in general terms and not restricted to the reason the verse was revealed or the hadith) it would be said that the hadith can be applied to all kind of cheating and fraudulence. In other words, this hadith should not be restricted to the companion who had weaknesses in his mind, but rather the ruling of the hadith comprises of every person who stipulates the absence of cheating and misrepresentation in a sale contract. Absolutely, the ignorant person (mustarsil) is including within the scope of the rulings of the hadith.

Furthermore, the Islamic law or Shariah as stated by Ibn al-Qayyim (1991) is based on wisdom and achieving people's welfare in this life and the afterlife. Shari'ah is all about justice, mercy, wisdom and good. It means that Shariah stands with the right wherever it is found. Hence, standing with those who is weak or ignorant in the selling and buying dealings should be in a main concern particularly those who do not know how to protect themselves and their wealth from the oppressors.

In this connection, we have chosen the opinion which says that bay istirsal can be regarded as a particular contract that has its own rule and implications in Shari'ah. Thus, if the person enters the contract of sale based on his trust with the seller, then he is cheated by overcharging upon the price, the Shari'ah gives the right of option to revoke the contract in order to meet the objective of justice and fairness in transaction dealings. Some of the jurists opined that ghabn or ghabn fahish should in all cases be accompanied by tadlis or taghrir in order to constitute the nullification of the contract.

\section{Relationship between Bay Istirsal and Khiyar Ghabn}

As we have mentioned that this type of sales concluded by a person who is weak or ignorant of the price or someone who relies merely on his trust with the seller. It occurs when the buyer for instance discloses secret about himself indicating that he has no knowledge pertaining to a particular object of contract, thus putting his trust in the seller that this latter would sell the good at the market price.

However, should the seller be fraudulent the buyer is granted the option to rescind the contract. This kind of option is known as khiyar al-ghabn. Based on this option that is given to the purchaser, it is clearly indicates the relationship between bay istirsal and khiyar ghabn. Similarly, as mentioned earlier that when discussing the effect of ghabn on contract, jurists will normally touch in somewhat detail three types of practices namely talaqqi al-rukban, najash and mustarsil. 
INTERNATIONAL JOURNAL OF ACADEMIC RESEARCH IN ACCOUNTING, FINANCE AND MANAGEMENT SCIENCES

Vol. 10, No. 3, 2020, E-ISSN: 2225-8329 @ 2020 HRMARS

Ghabn has been defined as an imbalance between the value of a subject matter of a contract and the consideration paid for it, for example, by paying a higher or lower than the market price. It can be divided into two types, namely ghabn fahish and ghabn yasir with the former meaning excessive imbalance and the latter, small imbalance (Abdul Jabbar, 2012). In other words, ghabn fahish means excessive loss suffered by a party to the contract as a result of concealment or misrepresentation, or deception or fraud practiced by the other. Whether the loss is excessively or not is to be ascertained in view of the market value of the subject matter. Ghabn is regarded light (yasir) if the difference between the price at which goods were sold and their real market is so small that the merchants do not generally take it into account in their dealings.

\section{Conclusion}

Based on the different views of scholars, the Sharia concern that has been raised by jurists is the right of purchaser in bay istirsal to revoke contract when the element of fraud and cheating is present or absent. However, from its validity, they agree that the contract is considered valid at very beginning. Thus, the paper can safely conclude that bay istirsal is valid contract. However the purchaser is entitled to the right to revoke the contract should there is element of fraud or cheating. The study also suggests that bay istirsal is one of the important Sharia contracts that may be used in the current Islamic finance. The differences among scholars in its ruling and implications should be benefited by the current practices of Islamic finance. However, to ensure that bay istirsal be practiced appropriately, the jurists should seriously consider maqasid approach and avoid any element of violating Sharia rules. Therefore, having known that this study is a pure Sharia and fiqhi research, more comprehensive research in the future needs to be done on the possibility of developing new instrument based on bay istirsal.

\section{References}

Al-Bashir, M. (2008). Risk Management in Islamic Finance An analysis of Derivatives Instruments in Commodity Markets. Brill's Arab and Islamic Law series.

Al-Bayhaqi, A. B. A. (n.d). al-Sunan al-Kubra. Beirut: Dar al-Ma'rifah

Al-Bukhari, M. B. I. (1987). al-Sahih. Beirut: Dar Ibn Kathir. Tahqiq: Dr. Mustafa Dib al-Bugha.

Al-Haytami, A. B. M. B A. (n.d). Tuhfat al-muhtaj fi sharh al-minhaj. Beirut: Dar Ihya' al-Turath alArabi.

Al-Kasani, A. B. M. (1986). Bada'i' al-sanai' fi tartib al-sharai'. Beirut: Dar al-Kutub al-Ilmiyyah

Al-Mardawi, A. B. S. (n.d). Al-Insaf. Beirut Dar Ihya' al-Turath al-Arabi

Al-Nawawi, Y. B. S. (n.d). al-Majmu sharh al-muhadhdhab. Matba'ah al-mutiriyyah

Al-Nishwan, S.B. M. (1425). Hukm al-ghabn wa atharuhu fi al-aqd. Majallat al-Adl. No. 23, pg. 79-98.

Al-Suyuti, J. D. (1994). Jami'al-Ahadith. Beirut: Dar al-Fikr

Bacha, O. I. (2008). The Islamic interbank money market and a dual banking system: the Malaysian experience. International Journal of Islamic and Middle Eastern Finance and Management. Vol. 1 No. 3, pp. 210-226. https://doi.org/10.1108/17538390810901140

Dusuki, A. W. (2009). Shariah Parameters on Islamic Foreign Exchange Swap as Hedging Mechanism in Islamic Finance. Paper presented in International Conference on Islamic Perspectives on Management and Finance. University of Leicester; $2^{\text {nd }}-3^{\text {rd }}$ July 2009.

Abdul Jabbar, F. S. (2012). Insider dealing: fraud in Islam?. Journal of Financial Crime. Vol. 19 No. 2, pp. 140-148. https://doi.org/10.1108/13590791211220412 
INTERNATIONAL JOURNAL OF ACADEMIC RESEARCH IN ACCOUNTING, FINANCE AND

\section{MANAGEMENT SCIENCES}

Vol. 10, No. 3, 2020, E-ISSN: 2225-8329 @ 2020 HRMARS

Fleming, M. J., \& Garbade, K. D. (2003). The repurchase agreement refined: GCF repo. New York: Current issues in economics and finance

Hasan, A. (2008). Pengertian al-wa'ad, al-wa'adan dan al-muwa'adah. Muzakarah Cendikiawan Syariah Nusantara 2008.

Ibn Juzayy, M. B. A. (2013).Beirut: Dar Ibn Hazm

Ibn Manzur, M. B. M. (n.d). Lisan al-Arab. Beirut: Dar al-Sadir

Ibn al-Qayyim. M. (1991). I'lam al-muwaqqi'in an rabb al-alamin. Beirut: Dar al-Kutub al-Ilmiyyah.

Ibn Qudamah, M. D. (1985). al-Mughni. Beirut: Dar Ihya' al-Turath al-Arabi.

Ibn Taymiyyah, T. D. (1995). Majmu' fatawa Ibn Taymiyyah. Majmak al-Malik Fahad

International Shari'ah Research Academy for Islamic Finance ISRA. (2010). ISRA Compendium

Islahi, A. (2005). Contributions of Muslim Scholars to Economic Thought an Analysis (11-905A.H./6321500 A.D). Journal of King Abdel Aziz University: Islamic Economic, Vol. 20, No, 2, pp: 53-62.

Khan, M. A. (2003). Islamic Economics and Finance: A Glossary. $2^{\text {nd }}$ edition. Taylor and Francis eLibrary.

Ministiry of Awqaf of Kuwait. (1983). Mawsu'ah al-Fiqhiyyah al-Kuwaytiyyah. (The Encyclopaedia of Islamic Law)

Muslim, A. H. (1995) Al-Jami' al-sahih al-musamma bi sahih Muslim. Beirut: Dar al-Jil.

Omar, M. N., Arifin, M., Napiah, M. D., \& Abdullah, M. A. (2011). The Implications of Ghubn in Islamic Contracts: An Analysis Of Current Practices. Journal of Applied Sciences Research, 7(13): $2177-$ 2181, 2011. ISSN 1819-544X. 